\title{
Increasing levels of zeolite and Yucca schidigera in diets for adult cats
}

\author{
Natália Charleaux Roque ${ }^{1}$, Flávia Maria de Oliveira Borges Saad ${ }^{1}$, João Paulo Fernandes \\ dos Santos ${ }^{1}$, Fernanda Sayuri Ebina ${ }^{1}$, Ana Flávia Chizzotti ${ }^{1}$, Rosana Claudio Silva ${ }^{1}$, Adriana \\ Augusto Aquino ${ }^{1}$, Gustavo Vaz Corrêa Maia ${ }^{1}$
}

\begin{abstract}
${ }^{1}$ Departamento de Zootecnia - UFLA.
ABSTRACT - The effect of the additives Yucca schidigera (YSC) and zeolite (clinoptilolite) on digestibility, fecal texture and odor, blood parameters and urine $\mathrm{pH}$ of domesticated felines was evaluated. The experiment was conducted in a randomized block design, with twenty-one cats, in two periods, distributed in seven treatments: moist commercial feed (control); control + 125, 250 and 375 ppm YSC; and control + 0.5; 0.75 and $1.0 \%$ zeolite. No differences were observed between the diets regarding apparent digestibility coefficients of nutrient, energy, urine $\mathrm{pH}$ or blood parameters. However, levels of 0.5 and $0.75 \%$ zeolite were effective both in reducing odor $\left(R^{2}=96.39\right)$ and for fecal texture $\left(R^{2}=99.63\right)$, showing a quadratic pattern for these variables. Levels of 125 and 375 ppm YSC were also efficient in reducing fecal odor; however they did not adjust to regression. Levels of $0.5 \%$ and $0.75 \%$ zeolite significantly reduce odor of feces and increase fecal texture when added to commercial feed for cats.
\end{abstract}

Key Words: additives, digestibility, fecal odor, felines, nutrition

\section{Introduction}

Pet nutrition is different from farm animal nutrition, as it aims at the quality of life for these animals during their aging. So, pet nutrition is focused on preventing problems that could compromise the animal throughout its life. However, this is not the only thing that owners have been worrying about. The closeness of animals to their owners has caused discomfort related to feces odor (Maia et al., 2010). The reduction in the odor can be achieved through the use of raw materials with high digestibility. This effect can be enhanced by the use of additives such as Yucca schidigera extract, which inhibits the urease by the extract's saponin fraction (Preston et al., 1987) and is an alternative source of fiber, which helps in reducing the intestinal transit (McFarlane \& Metheney, 1998); or with the inclusion of zeolite (hydrated aluminum silicates), which has properties such as adsorption of gas, fumes and water (Pond et al., 1995) that, somehow, will act on the mechanisms that contribute to the bad odor in feces. Currently, there is a great scientific interest in the usage of both Yucca schidigera extract (YSC) and zeolite, additives classified as odor reducers (Anfalpet, 2008), due to their extensive range of functional properties.

With the addition of new ingredients to the diet, it is necessary to investigate if such action causes or will cause some negative effects to the health of these animals. Hematologic parameters provide information on clinical and nutritional statuses as well as on treatment and prognosis for the animals (González et al., 2003). Furthermore, they reflect the metabolic status of tissues and may indicate injuries, disorders in the functioning of organs, animal adaptation to nutritional and metabolic imbalance challenges (González \& Scheffer, 2003).

For this matter, the objective of this research was to evaluate the effects of the addition of 125, 250 and $375 \mathrm{ppm}$ Yucca schidigera in dry matter and zeolite at the levels $0.5,0.75$ and $1.0 \%$ of dry matter on the digestibility, fecal texture and odor, blood parameters and urinary $\mathrm{pH}$ of domestic cats.

\section{Material and Methods}

The test trial consisted of two periods to determine the apparent digestibility coefficient of the experimental diets. Blood samples were collected for laboratory analysis, measuring the $\mathrm{pH}$, urinary volume and fecal texture from both periods, and at the end of the second period, samples were collected for assessment of fecal odor.

Twenty-one mongrel, adult, vaccinated and dewormed male and female cats, with average age of $3 \pm 0.84$ years old, weighing $3.71 \pm 0.84 \mathrm{~kg}$ were housed in metabolism room and kept in individual metabolism cages. Cats underwent clinical examination, and it was verified that they were healthy. Urine analyses were also conducted in order to prove the integrity of the urinary tract in the animals and to 
ensure the analysis of a possible influence of the diet on the $\mathrm{pH}$. A randomized block design was used, in which animals were distributed into seven diets, each one with three animals, during two periods, totaling seven treatments and six replications. The treatments supplied to each of the groups were: moist commercial feed (control; Table 1), control $+125,250$ and 375 ppm Yucca schidigera and control + 0.5, 0.75 and $1.0 \%$ zeolite. Levels were calculated based on dry matter in the feed.

Table 1 - Chemical composition (\% natural matter) and basic composition of control feed*

\begin{tabular}{lc}
\hline Nutritional level & $\%$ \\
\hline Moisture & 78 \\
Crude protein & 8 \\
Ether extract & 4.7 \\
Crude fiber & 0.7 \\
Mineral matter & 3.0 \\
Metabolizable energy & $967 \mathrm{kcal} / \mathrm{kg}$ \\
\hline * Water, animal byproduct, rice meal, rice gluten, powder cellulose, vegetable \\
oil, sodium phosphate, taurine, ascorbic acid, fructooligosaccharides, vitamin \\
mineral premix and transchelated micromineral premix.
\end{tabular}

The amounts of supplied food were based on energy requirements estimated by the equation $100 \mathrm{kcal} \times \mathrm{BW}^{0.67}$ (NRC, 2006). Diets were supplied to the animals once a day, in the morning, as well as total feces collection. At the time of collection, the fecal texture was determined, according to the scale used by Parreira (2003). Both feces and feed leftovers were collected daily, identified, weighed and stored in a freezer $\left(-20^{\circ} \mathrm{C}\right)$. The samples, after pre-drying, were crushed in a Thomas-Wiley mill with a 1-mm sieve and set aside for composition analysis according to AOAC (1991). To evaluate the apparent digestibility coefficients, the levels of DM, CP, mineral matter and gross energy in feces and food samples were determined. The measurement of gross energy was made in a PARR adiabatic calorimetric bomb, according to the procedure described by Silva \& Queiroz (2002). The digestibility coefficient was calculated using the formula: nutrient DC $=[$ ( $g$ feed consumed $\times \%$ of nutrient in the feed) - ( $g$ feces $\times \%$ excreted nutrient)] / ( $g$ of feed consumed $\times \%$ of nutrient in the feed $) \times 100$.

The measurement of urine $\mathrm{pH}$ of each animal was performed at the end of each period, as well as blood collection. Urine $\mathrm{pH}$ was measured using a digital $\mathrm{pH}$ meter, according to procedures recommended and described by Anfalpet (2008). Blood samples were taken from animals that fasted for about 8 hours, and placed into two different tubes: one tube containing heparin for urea analysis, creatinine and $\mathrm{CBC}$; the other one without heparin, wrapped in foil, in order to avoid contact with light, for bilirubin and fractions analyses. Samples were cooled and conducted to the laboratory where creatinine, urea, bilirubin and fraction contents were measured, and CBC was conducted.

Samples of fresh feces were collected for sensory evaluation at the end of the second period, by possible owners and, thus, by cat feed buyers. The analysis was conducted according to information described by AnzaldúaMorales (1994), with adaptations. The evaluation was made comparing the material numbered from 1 to 6 , referring to the experimental treatments with the levels of additives to the material called standard (S), referring to experimental treatment without any additive. Grades were attributed to each sample, as follows: 0 = extremely foul, more than the standard, 1 = more malodorous than the standard, 2 = similar to the standard, 3 = less malodorous than the standard, $4=$ considerably less malodorous than the standard.

The results were analyzed using the Statistical Analysis System computer software (SAS Institute, 2004), with normality of the residues and homogeneity of variances previously verified. Variables that did not meet the assumptions were transformed, and when the transformation was ineffective, they were evaluated by non-parametric statistics (Kruskal Wallis test), through PROC NPAR1WAY from SAS.

\section{Results and Discussion}

There were no significant differences $(\mathrm{p}>0.05)$ in digestibility of any of the nutrients in the treatments, a result that is consistent with the observations by Dziuk et al. (1985), in a study with birds, and Maia et al. (2010), in research with the same levels used in this study, but with dogs.

The increased digestibility with the addition of zeolite, reported by Luz (1995), was not found in this study (Tables 2 and 3).

Cabuk et al. (2004) found a smaller amount of ash in the feces of broilers fed diets containing zeolite. In this study, no difference in ash digestibility was found, unlike the reports written by these authors.

Stool samples related to the diets containing 125 and 375 ppm Yucca schidigera and 0.5 and $0.75 \%$ zeolite presented, when compared with the control diet, better odor values ( $>0.05$ ) (Table 4). The supply of diets with $1.0 \%$ zeolite and 250 ppm Yucca schidigera, however, resulted in a different behavior. The diet with $1.0 \%$ zeolite was considered similar to the control and inferior when compared with the other treatments, but superior when compared with the diet with $250 \mathrm{ppm}$ Yucca schidigera. This one, however, showed a value corresponding to the foulest odor in comparison with all other treatments, including the control. 
Table 2 - Mean values for apparent digestibility coefficient of dry matter, crude protein and mineral matter for grown cats

\begin{tabular}{lccc}
\hline Diet & & \multicolumn{2}{c}{ Apparent digestibility coefficient } \\
\cline { 2 - 4 } & Dry matter $(\%)$ & Crude protein (\%) & Mineral matter (\%) \\
\hline Control & $77.67 \pm 3.92$ & $82.91 \pm 4.04$ & $31.48 \pm 12.14$ \\
125 ppm Yucca schidigera & $77.44 \pm 5.10$ & $83.47 \pm 5.02$ & $27.60 \pm 8.33$ \\
250 ppm Yucca schidigera & $77.41 \pm 4.49$ & $84.43 \pm 2.70$ & $34.90 \pm 8.44$ \\
375 ppm Yucca schidigera & $77.72 \pm 3.19$ & $82.64 \pm 3.07$ & $28.98 \pm 8.77$ \\
$0.5 \%$ zeolite & $76.60 \pm 2.44$ & $83.45 \pm 3.39$ & $25.54 \pm 8.09$ \\
$0.75 \%$ zeolite & $75.96 \pm 2.95$ & $82.46 \pm 2.89$ & $22.14 \pm 7.98$ \\
$1.0 \%$ zeolite & $76.98 \pm 3.91$ & 4.12 & $23.50 \pm 13.27$ \\
CV (\%) & 4.62 & 36.40 & 36 \\
\hline
\end{tabular}

Means followed by different letters in the column differ by the SNK test at $5 \%$ significance.

Table 3 - Mean values for apparent metabolizable energy in natural matter (kcal/kg) and in dry matter (kcal/kg)

\begin{tabular}{lcr}
\hline Treatment & $\begin{array}{c}\text { Apparent metabolizable energy } \\
\text { in dry matter (kcal/kg) }\end{array}$ & $\begin{array}{c}\text { Apparent metabolizable energy } \\
\text { in }\end{array}$ \\
\hline Control & $4,452.65 \pm 150.61$ & $976.47 \pm 33.03$ \\
$125 \mathrm{ppm}$ Yucca schidigera & $4,499.65 \pm 190.03$ & $1,022.32 \pm 43.18$ \\
$250 \mathrm{ppm}$ Yucca schidigera & $4,481.22 \pm 129.98$ & $1,004.69 \pm 29.14$ \\
$375 \mathrm{ppm}$ Yucca schidigera & $4,478.20 \pm 125.01$ & $999.54 \pm 27.90$ \\
$0.5 \%$ zeolite & $4,417.56 \pm 84.30$ & $980.70 \pm 18.72$ \\
$0.75 \%$ zeolite & $4,399.54 \pm 116.68$ & $985.93 \pm 26.15$ \\
$1.0 \%$ zeolite & $4,418.04 \pm 128.35$ & $1,007.79 \pm 29.28$ \\
CV (\%) & 2.94 & 3.24 \\
\hline
\end{tabular}

Means followed by different letters in the column differ by the SNK test at 5\% significance.

Table 4 - Scores of feces texture and odor from cats fed with feed containing Yucca schidigera or zeolite

\begin{tabular}{|c|c|c|}
\hline Treatment & Feces score & Odor \\
\hline Control & $3.23 \pm 0.90 \mathrm{a}$ & $2.00 \mathrm{~b}$ \\
\hline 125 ppm Үисса schidigera & $3.63 \pm 0.60 \mathrm{a}$ & $2.57 \pm 0.93 c$ \\
\hline 250 ppm Yucca schidigera & $3.20 \pm 0.60 \mathrm{a}$ & $1.17 \pm 1.06 \mathrm{a}$ \\
\hline 375 ppm Yисса schidigera & $3.60 \pm 1.00 \mathrm{a}$ & $2.38 \pm 0.92 c$ \\
\hline $0.5 \%$ zeolite & $4.30 \pm 0.70 \mathrm{~b}$ & $2.55 \pm 1.00 \mathrm{c}$ \\
\hline $0.75 \%$ zeolite & $4.27 \pm 0.60 \mathrm{~b}$ & $2.23 \pm 0.96 \mathrm{c}$ \\
\hline $1.0 \%$ zeolite & $3.67 \pm 0.70 \mathrm{a}$ & $1.87 \pm 1.11 \mathrm{~b}$ \\
\hline CV (\%) & 20.22 & 14.24 \\
\hline
\end{tabular}

Means followed by different letters in the column differ by the Scott-Knott test at $5 \%$ significance.

The initial concentration of total ammonia decreases as zeolite is added; however the data behavior presented in this study are supported by the finding of Sonnenholzner (2004), which showed that the adsorbents are more effective when there is high concentration of solute related to the adsorbent. The authors found, by including $1 \mathrm{~g}$ zeolite, the removal of total ammonical-N at $1.53 \mathrm{mg} / \mathrm{g}$. However, by adding $10 \mathrm{~g}$ zeolite, the removal was $0.91 \mathrm{mg} / \mathrm{g}$.

The diet with $250 \mathrm{ppm}$ Yucca schidigera was similar to control and to $1.0 \%$ zeolite, and this fact can be explained by the huge variation among animals, concerning fecal odor composition and, especially, the high subjectivity of the sensory panel analysis.

There were differences $(\mathrm{p}<0.05)$ between the feces scores (Table 4 ) in the different treatments. Although diets did not present differences concerning nutrient digestibility, a result that could justify higher fecal score, treatment with 0.5 and $0.75 \%$ presented higher fecal scores than the others, probably due to the high hygroscopicity of zeolite, which absorbs the free water present in the gastrointestinal tract, carrying the excess water.

The fact that the diet with higher amounts of zeolite additive was not similar can be explained by the relationship between the amount of solute and adsorbent.

Contrary to this, Maia et al. (2010) found higher scores for samples from dogs under treatment with the inclusion of 0.75 and $1.0 \%$ zeolite. In this experiment, zeolite presented a quadratic behavior (Figure 2) in relation to fecal odor, and the inclusion of $0.46 \%$ zeolite was the level that showed the highest reduction of odor. Furthermore, the higher levels show a decreasing trend regarding fecal odor response, similarly to fecal score (Figure 1), which presented the ideal level at $0.56 \%$ to obtain the ideal fecal scores. Higher zeolite inclusions tend to cause reduced fecal score values, i.e., softer stool. Although Yucca schidigera has shown significant effect on fecal odor, it showed no adjustments for regression.

Although Glauert et al. (1962) have reported hemolytic saponins, this action was not detected in this experiment, because the indirect bilirubin levels (Table 5) did not vary between the diets $(\mathrm{p}>0.05)$. Moreover, hemoglobin did not differ between groups ( $>0.05$ ) either. Lowe \& Kershaw (1997) also found no changes in hematological counts. For rats, Preston et al. (1987) have found that the use of 
Yucca schidigera in the feed decreases the serum concentration in the urea. Colina et al. (2001) have noticed no change in blood urea of pigs, as Maia et al. (2010) has found no difference between the values of blood urea for dogs fed diets containing 250 ppm Yucca schidigera and $0.75 \%$ zeolite when compared with the control feed. Likewise, in this study there was no difference in the levels of urea (Table 5) and creatinine (Table 6) ( $\mathrm{p}>0.05$ ).

Since the water intake was not measured, the hematocrit was evaluated and, as there was no statistical difference

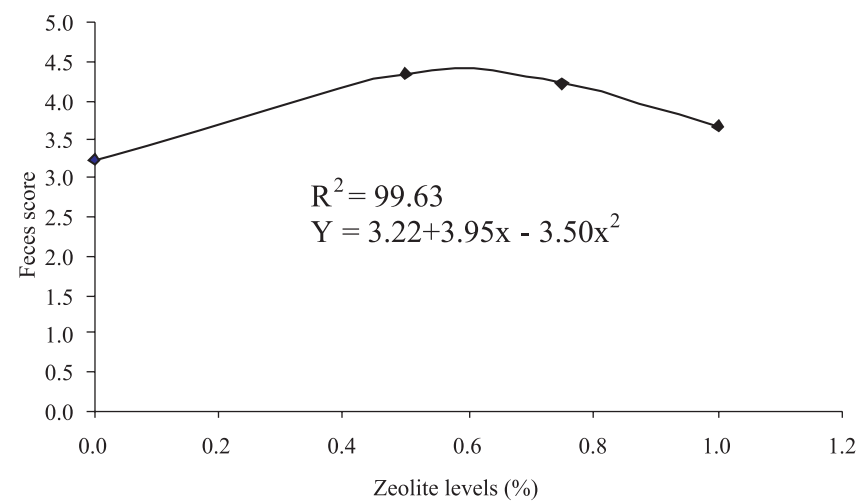

Figure 1 - Mean values for fecal score according to zeolite levels (\%).
( $>0.05$ ) in this parameter (Table 6), the difference in fecal score found in this study can be attributed to the additive action and not to changes in water intake.

The inclusion of zeolite in the diet did not cause changes in the urinary pH (Table 7) of cats, despite its high capacity for cation exchange. There were no reports about a possible influence of Yucca schidigera extract on urinary $\mathrm{pH}$ of cats. In this study, there was no change in urinary $\mathrm{pH}$ that could be attributed to the inclusion of Yucca schidigera extract.

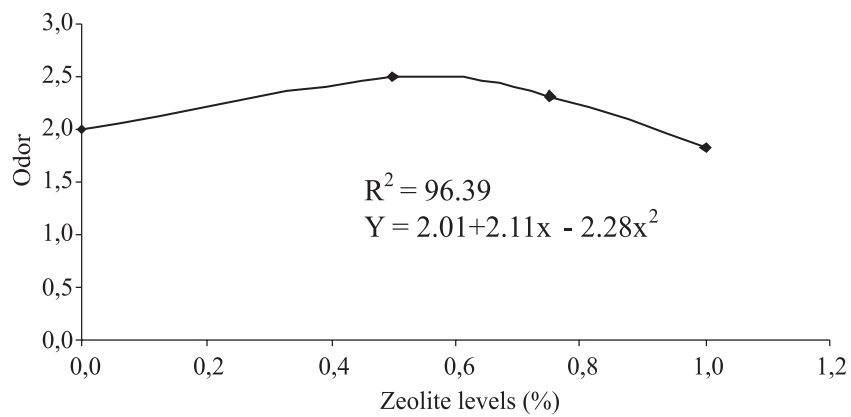

Figure 2 - Average values attributed to feces odor according to zeolite levels (\%).

Table 5 - Mean values for hemoglobin, indirect bilirubin and urea in blood samples of cats in the different additive levels

\begin{tabular}{|c|c|c|c|}
\hline$\overline{\text { Diet }}$ & Hemoglobin (g/gL) & Indirect bilirubin $(\mathrm{mg} / \mathrm{dL})$ & Urea $(\mathrm{mg} / \mathrm{dL})$ \\
\hline Control & $14.12 \pm 2.06$ & $0.1967 \pm 0.23$ & $40.50 \pm 5.79$ \\
\hline 125 ppm Yucca schidigera & $14.90 \pm 1.37$ & $0.2367 \pm 0.14$ & $48.17 \pm 4.75$ \\
\hline 250 ppm Yисса schidigera & $15.10 \pm 1.25$ & $0.2800 \pm 0.15$ & $46.33 \pm 5.24$ \\
\hline 375 ppm Yuсca schidigera & $14.48 \pm 2.22$ & $0.1483 \pm 0.10$ & $45.17 \pm 4.36$ \\
\hline $0,5 \%$ zeolite & $15.47 \pm 0.98$ & $0.2333 \pm 0.16$ & $46.00 \pm 5.66$ \\
\hline 0,75\% zeolite & $14.65 \pm 1.91$ & $0.2333 \pm 0.19$ & $48.50 \pm 6.22$ \\
\hline $1,0 \%$ zeolite & $14.57 \pm 1.24$ & $0.2833 \pm 0.19$ & $39.83 \pm 5.12$ \\
\hline CV (\%) & 10.35 & 35.47 & 12.20 \\
\hline
\end{tabular}

The data for bilirubin were transformed by quadratic root for statistical analysis.

Means followed by different letters in the column differ by Scott-Knott test at $5 \%$ significance.

Table 6 - Mean values for creatinine (mg/dL) and hematocrit from blood samples of cats under different additive levels

\begin{tabular}{lcc}
\hline Diet & Creatinine & Hematocrit \\
\hline Control & $14.12 \pm 2.06$ & $40.50 \pm 5.79$ \\
$125 \mathrm{ppm}$ Yucca schidigera & $14.90 \pm 1.37$ & $48.17 \pm 4.75$ \\
$250 \mathrm{ppm}$ Yucca schidigera & $15.10 \pm 1.25$ & $46.33 \pm 5.24$ \\
$375 \mathrm{ppm}$ Yucca schidigera & $14.48 \pm 2.22$ & $45.17 \pm 4.36$ \\
$0.5 \%$ zeolite & $15.47 \pm 0.98$ & $46.00 \pm 5.66$ \\
$0.75 \%$ zeolite & $14.65 \pm 1.91$ & $48.50 \pm 6.22$ \\
$1.0 \%$ zeolite & $14.57 \pm 1.24$ & $39.83 \pm 5.12$ \\
Phosphorus & 0.0936 & 0.8693 \\
CV $\%$ ) & & 9.72 \\
\hline
\end{tabular}

Means for creatinine did not differ by Kruskal-Wallis test.

Means for hematocrit did not statistically differ by the F. test. Both are at $5 \%$ significance.
Table 7 - Mean values for urine $\mathrm{pH}$ of cats fed diets containing Yucca schidigera or zeolite

\begin{tabular}{|c|c|}
\hline$\overline{\text { Diet }}$ & $\mathrm{pH}$ \\
\hline Control & $5.84 \pm 0.50$ \\
\hline 125 ppm Yисca schidigera & $5.74 \pm 0.53$ \\
\hline 250 ppm Yucca schidigera & $5.71 \pm 0.32$ \\
\hline 375 ppm Yuсca schidigera & $6.01 \pm 0.52$ \\
\hline $0.5 \%$ zeolite & $6.06 \pm 0.91$ \\
\hline $0.75 \%$ zeolite & $5.58 \pm 0.47$ \\
\hline $1.0 \%$ zeolite & $5.92 \pm 0.56$ \\
\hline CV (\%) & 8.62 \\
\hline
\end{tabular}

Means followed by different letters in the column differ by Scott-Knott test at 5\% significance. 


\section{Conclusions}

The supply of Yucca schidigera at levels of 125 and $375 \mathrm{ppm}$ increases the ability to reduce odors in the feces, as well as levels of 0.5 and $0.75 \%$ zeolite. However, these zeolite levels not only increase the ability to reduce the odor, but also improve fecal scores, promoting better results than those obtained with the other tested levels. Therefore, the use of 0.5 and $0.75 \%$ zeolite in commercial feed for cats is recommended, but further long term studies are needed in order to investigate the possible effects on the urinary $\mathrm{pH}$ of animals.

\section{References}

ANZALDÚA-MORALES, A. La evaluación sensorial de los alimentos en la teoría y la prática. Zaragoza: Acribia, 1994. 198 p.

ASSOCIAÇÃO NACIONAL DOS FABRICANTES DE ALIMENTOS PARA ANIMAIS DE ESTIMAÇÃO - ANFALPET. Manual do programa integrado de qualidade pet. São Paulo, 2008. 238p. (Informativo Técnico).

ASSOCIATION OF OFFICIAL ANALYTICAL CHEMISTS - AOAC. Official methods of analysis. 16.ed. Arlington, 1991. 1018p.

ÇABUK, M.; ALÇIÇEK, A.; BOZKURT, M. et al. Effect of Yucca schidigera and natural zeolite on broiler performance. International Journal of Poultry Science, v.3, n.10, p.651-654, 2004.

COLINA, J.J.; LEWIS, A.J.; MILLER, P.S. et al. Dietary manipulation to reduce aerial ammonia concentrations in nursery pig facilities. Journal of Animal Science, v.79, n.12, p.3096-3103, 2001.

DZIUK, H.E.; DUKE, G.E.; BUCK, R.J. et al. Digestive parameters in young turkeys fed yucca saponin. Poultry Science, v.64, n.6, p.1143-1147, 1985.

GLAUERT, A.M.; DINGLE, J.T.; LUCY, J.A. Action of saponin on biological membranes. Nature, v.196, p.953-955, 1962.

GONZÁLEZ, F.H.D.; CARVALHO, V.; MÖLLER, V. et al. Blood biochemical profile in dogs and cats under different feedings diets. Archives of Veterinary Science, v.8, n.1, p.23-27, 2003.

GONZÁLEZ, F.H.D.; SCHEFFER, J.F.S. Perfil sanguíneo: ferramenta de análise clínica, metabólica e nutricional. In: SIMPÓSIO DE PATOLOGIA CLÍNICA VETERINÁRIA DA REGIÃO SUL DO BRASIL, 2003, Porto Alegre. Anais... Porto Alegre: UFRGS, 2003. p.73-87.

LOWE, J.A.; KERSHAW, S.J. The ameliorating effect of Yucca schidigera extract on canine and feline faecal aroma. Research in Veterinary Science, v.63, n.1, p.61-66, 1997. LUZ, A.B. Zeólitas: propriedades e usos industriais. Rio de Janeiro: CETEM/CNPq, 1995. 35p. (Tecnologia Mineral, v.68).

MAIA, G.V.C; SAAD, F.M.O.B; ROQUE, N.C. et al. Zeólitas e Yucca schidigera em rações para cães: palatabilidade, digestibilidade e redução de odores fecais. Revista Brasileira de Zootecnia, v.39, n.11, p.2442-2446, 2010.

McFARLANE, J.M.; METHENEY, C.D. Effect of dietary Micro Aid on canine fecal odour. Porterville: Report, Distributors Processing Inc, 1998. p.67-71.

NATIONAL RESEARCH COUNCIL - NRC. Nutrient requirements of dogs and cats. Whashington: Nacional Academy of Science, 2006. 398p.

PARREIRA, P.R. Efeito de dois alimentos comerciais secos e dois fornecimentos no consumo alimentar, peso vivo e metabólico, escore corporal, escore e volume fecal de cães adultos em atividade. 2003. 84f. Dissertação (Mestrado em Qualidade e Produtividade Animal) - Universidade de São Paulo, São Paulo.

POND, W.G.; CHURCH, C.D.; POND, K.R. Basic animal nutrition and feeding. 4.ed. New York: John Wiley, 1995. 615p.

PRESTON, R.L.; BARTLE, S.J.; MAY, T. et al. Influence of sarsaponin on growth, feed and nitrogen utilization in growing male rats fed diets with added urea or protein. Journal of Animal Science, v.65, n.2, p.481-487, 1987.

SILVA, D.J.; QUEIROZ, A.C. Análise de alimentos: métodos químicos e biológicos. 3.ed. Viçosa, MG: UFV, 2002. p.39-45.

SONNENHOLZER, S. Ensayo de remoción de amonio por mineral zeolita: efecto del radio del soluto (amonio) con respecto al absorbente (zeolita). Cenaim Informa: Boletin Informativo, Guayaquil, n.110, p.1-1, 2004. Available at: <http://www.cenaim.espol.edu.ec/ publicacionesquincenal/bquinc110.pdf $>$. Accessed on: Sept. 10, 2009.

STATISTICAL ANALYSIS SYSTEM - SAS. User's guide: statistics. Version 9.1.1. Cary: 2004. (CD-ROM). 